\title{
The importance of a differentiated representation of information for Contemporary Art: Use of fruition as a classification attribute ${ }^{1}$
}

\author{
A importância da representação da informação \\ diferenciada para a Arte Contemporânea: a \\ fruição como atributo de classificação
}

Thais CATOIRA²

Carlos Xavier de AZEVEDO NETTO²

\begin{abstract}
The purpose of this study is to discuss information and art analyzing, through the representation of information, the role of Information Science. It is a discussion about the representation of information of Contemporary Art through the collaborative work among professionals. Information Science can contribute to the treatment and organization of information since it addresses the representation of information in different contexts and materials, reducing the complexity of these objects based on the possibility of abstraction and fruition. It includes a critical reflection based on artists'books that are part of the Paraiba's Center for Contemporary Art Collection. It was found that there is a tendency to homogenize the treatment of information of artworks through descriptive representation.
\end{abstract}

Keywords: Artist's books. Contemporary art. Information Science. Representation of information.

\section{Resumo}

Discute informação e arte ao analisar a atuação da Ciência da Informação através da representação da informação. Trata-se de uma discussão sobre a representação da informação de obras de Arte Contemporânea, através do trabalho colaborativo entre profissionais. A Ciência da Informação por pensar sobre a representação da informação em diferentes contextos e suportes poderia auxiliar no tratamento e organização das informações, amenizando a complexidade desses objetos a partir de suas possibilidades de abstração e fruição. Reflete-se criticamente a partir dos livros de artistas, do acervo do Núcleo de Arte Contemporânea - Paraíba. Considera-se que prevalece uma tendência de homogeneizar os tratamentos das informações das obras por meio da representação descritiva.

Palavras-chave: Livros de artista. Arte contemporânea. Ciência da Informação. Representação da informação.

\section{Introduction}

Information Science, traditionally associated with actions that include the use of interdisciplinary approaches, involves different disciplines based on theoretical approaches in order to understand and analyze its subject of study - information - in different contexts through cooperation and information

\footnotetext{
1 Article based on the master dissertation the T. CATOIRA, entitled "Informação e arte: memórias e representação do acervo do Núcleo de Arte Contemporânea da Paraíba". Universidade Federal da Paraíba, 2012

2 Universidade Federal da Paraíba, Centro de Ciências Sociais Aplicadas, Programa de Pós-Graduação em Ciência da Informação. Campus I, Castelo Branco, 58051-900, João Pessoa, PB, Brasil. Correspondência para/Correspondence to: C.X. AZEVEDO NETTO. E-mail:<xaviernetto@gmail.com>.

Received in 10/6/2015, resubmitted on 11/11/2015 and approved in 18/1/2016.
} 
socialization aiming at the treatment, organization, and dissemination of information (Loureiro, 2002).

This study will discuss information and art, objects of study of different areas of knowledge, in order to analyze, through the representation of information, the role of Information Science beyond the traditional conception of representation, in which its function is to access the information contained within the document for its use and generation of new information and knowledge (Pinho, 2009).

Information is understood as a social phenomenon that promotes new meanings when present in a specific time-space, and it can be available in different ways of storing records, i.e., information can be seen as an artifact that promotes new interpretations in different contexts (Azevedo Netto, 2002; Catoira, 2012). Considering that the essence of information phenomenon as a human product inserted in a sociocultural context (Pacheco, 1995) is its representation, which in a few words means to present something that was obscure, it can be said that in the field of Information Science, representation of information aims to demonstrate the essence of the document (selection of features and attributes that are peculiar to the object or event) through its recodification previously established by a group of people in its sociocultural context for information retrieval (Catoira, 2012).

Accordingly, there has been an effort to find similarities between the conception of symmetry proposed by Latour (1994) and the theory of agency by Gell (1998), which makes reference to the interaction of the elements that make up a particular artwork within a system of action which, in addition to the art object itself, involves the environment, spectators, and artists. Latour's symmetrical anthropology contests the asymmetry of the anthropological thought, giving a place for the causal agency of both subjects and objects in order to see the multiplicity of things, allowing these entities to have new concepts in terms of materiality (Knappett, 2012). As a result of such relationships and equivalence, the various products of human activities would be compared to their constituents in a flowing dynamics and interdependent actions.

Aiming at demonstrating the essence of the document, the representation of information occurs based on the construction of a new language, previously established by a group of people or voluntarily agreed within a sociocultural context, focusing on an efficient information retrieval. Making a representation involves a selection of features and attributes that are peculiar to the object. However, it is important to understand that it is not possible to represent the totality of information of an object. Although the representation process is limited, it effectively helps the understanding of the world and the sociocultural knowledge and contributes to the treatment and organization of memories of the societies (Martins, 2008).

Establishing a dialogue between "art objects" and "information" through methodological and theoretical aspects of Information Science can contribute to the preservation, organization, dissemination, access, and even legitimation, through the production of documentation regarding institutional issues that involve, for example, recording ephemeral productions.

It is worth mentioning that the process of representation of information of art objects involves informational and contextual characteristics, which means analysis and organization different from that used in libraries and archives for item classification. Therefore, the idea of representation, as well as the idea of concept, has gained semiotic contours (Azevedo Netto, 2008a), since it has to be analyzed according to its elements, which are not isolated in time and space and comprise a specific situation.

Therefore, according to Pinheiro (1996), the information scientist would be responsible for the development of methodologies specific to these artistic materials, avoiding a partial and fragmented vision, ensuring the communication between professionals from different areas (archivists, librarians, museum curators, art historians, and artists) focusing on the understanding of the artistic creation process, the contextualization of the art work in time and space, and the analysis of intrinsic and extrinsic information of these artistic productions. In the context, according to the Classificação Brasileira de Ocupações Brazilian Occupational Classification, (Brasil, 2002), the definition of information professional encompasses different professionals, including the information scientist; but for the purpose of this article, information scientist is defined as a professional who studies the behavior of information in various contexts and forms and the professional who 
works with information processing and organization, such as archivists, librarians, and museum curators; professionals included in the information professional category.

The objective of the present study is to discuss the representation of information of contemporary art through the collaborative work between scientists and information professionals, exploring its interdisciplinary approach. Information Science could therefore, through this cooperation, contribute to the treatment and organization of information in order to reduce the complexity of contemporary artworks due to their possibilities of abstraction and fruition.

Accordingly, the initial purpose of this article is to understand the relationship between work of art and museums, the adopted methods of representation, and the different issues that are involved and that can result from the production of contemporary art. Subsequently, it aims to conduct a critical analysis to examine these issues based on the representation of information of artists' books that are part of the Núcleo de Arte Contemporânea da Paraíba (NAC, Paraiba's Center for Contemporary Art collection). About the artistic books, they can be understood as artistic products that have the shape concept of extrapolation book but, desconstruction and modify the design en a plastic construction created by an artist based on his/her experiences (Silveira, 2008).

\section{Contemporary productions: Influences, issues, and reflections}

Historically, the relationship between work of art and museums allowed artworks to become part of these settings more often from the nineteenth century onwards with the primary goal of aesthetic contemplation. In museums, the conceptions were associated to the attribute of power and value; later they involved administrative and exhibition issues without, however, exploring the potential of their art objects as a source of information, with little focus on research, memories, and information retrieval (Pinheiro, 1996; Rodrigues \& Crippa, 2009).

Art museums started to influence artistic productions, which, in turn, promoted reflections and new adaptations in these spaces. Consequently, the understanding of what a work of art is, or even the concept of art, could still be considered as a process that presents mutual influences and that undergo permanent transformations aiming to establish its conceptual contours.

Therefore, not all of the works of art produced today can be considered contemporary art since this type of production involves aesthetic, critical, political, social, and ethnic reflection; sometimes the aesthetic aspects of the final material are not taken into consideration (Martins, 2008). Contemporary art museums have a variety of art productions, providing their visitors with an experience based not only on materiality, but also on the processes of making, reflecting, and thinking, leading to signification and resignification with the socio-cultural and temporal contexts in which they are inserted.

In the field of visual arts, the term contemporary art, according to Ortiz Ramos et al. (2001), started to be used to describe the art productions created in the period after World War II; from the 1960s and onwards, these art productions have been created based on concepts, ideas, and theoretical or political reflections using different types of materials from those used to create traditional Western artwork (canvas, brush, paint, wood, etc.).

It can be said that both the museums of contemporary art and their artworks have broken the traditional concept, disengaging the long-term prestige and credit they used to have (Archer, 2001; Cauquelin, 2005). Andy Warhol's Campbell's soup cans, Duchamp's readymade are some examples of contemporary art that were created not only to be seen or contemplated but also to be thought-provoking or experienced to lead to new significations and sensations among its viewers.

Some contemporary works of art are produced "bound to die" or are produced for exterior public space display aiming to engage in a dialogue with the passerby. They can therefore be characterized as ephemeral or can be produced essentially for institutional settings (Archer, 2001; Cauquelin, 2005). Institutions rise to the challenge of seeking for new ways to store, treat, represent, preserve, and retrieve information from a diversity of materials that they safeguard as a way to preserve their information and the artworks in their materiality (Catoira, 2012).

The present study focuses on the discussion of representation of information regarding artists' books 
safeguarded in institutions; these books pertain to the production of conceptual art. But what is conceptual art? Briefly, conceptual art was an art movement that started between the 1960s and 1970s. It encompassed a multitude of artistic activities whose essence of production was the use of concepts and ideas as raw materials thus changing the focus, which used to be the materialization or production of artwork (Freire, 2009).

Within conceptual art, there is a type of production called artist's book, which is described by Silveira (2008, p.77) as "an artistic category (or practice) that develops both the experimentation of visual languages and the experimentation of possible expressions of the elements in the book [...]". The artist's book can be understood as "an artistic creation field"at the same time it is a product (Silveira, 2008, p.21).

This type of production leads to the need to understand the concepts of artists'books, concentrating attention on the extent, characteristics, specificities, and interpretative complexity of artistic abstraction, peculiar to works of art. The book offers its pages as a support for expression at the same time it can be deconstructed and its conceptual principles can be violated. This is a characteristic of contemporary art, i.e., "the reformer, transformer, or deconstructive gesture" (Silveira, 2008, p.21).

Seeing contemporary artworks as a document, respecting their conceptual and artistic characteristics, allows Information Science to study them based on different aspects and attributes, establishing new categories and signs in order to facilitate the provision and retrieval of information from materials that are produced for organization and preservation of the works of art of art center and museum collections and also to create databases of museums' collections or virtual collections.

Therefore, considering that conceptual art as well as other productions of material culture that are institutionalized by "officially" recognized places, such as museums, galleries, and art institutes among others, are considered as works of art. Besides having new artistic proposals (structural and conceptual), they also start to have new symbolic values and are considered informational sources, i.e. they are seen as documents and carriers of cultural and social memories. Thus,

The work of art considered as a museum object and source of information allows the aggregation of encrypted values. When thinking about the specificities inherent in the conceptual work of art, we highlight some aspects related to the material character of this production, together with the representation of the art object as a document. The meaning of a conceptual artwork is not conveyed in itself but through the place where it is included (Coelho, 2006, p.28, our translation) $)^{3}$.

Considering the representation of information of contemporary art objects, Information Science tends to promote the establishment of organization and composition of a documentary language that facilitates the retrieval of information. However, it should not lead discussions that are relevant only to the field of visual arts, in terms of aesthetics, visual composition, and artistic concepts, since the interdisciplinary dialogue is essential in this process that intends to analyze the information of the work of art as a document.

An analysis of the literature on art museums and representation of information of works of art, it can be observed that information systems and the methods of representation of the information of these objects have been little studied and have received modest investment in thesauri or specific terminology dictionaries that can facilitate the retrieval of information. Discussing works of art in general, including contemporary works of art, Bevilacqua (2010, p.82), highlights methodological approaches in his master's dissertation, as follows;

Despite the lack of methodological standard for such questions, it is possible to propose some criteria to define the classification parameters and destination of that particular type of materials (which are between the artistic object and the filed documents): artist's intention (mainly expressed in the object origin and formal configuration), support, technique, finishing, presentation, and the character of the finished work (defined more by the formal configuration of the object and its presentation than by the

\footnotetext{
3 "A obra de arte, como objeto museológico e fonte de informação, permite uma nova agregação de valores codificados. Ao refletirmos acerca das especificidades inerentes à obra de arte conceitual, ressaltamos alguns aspectos relacionados ao caráter material dessa produção em paralelo à representação do objeto artístico como documento. Osignificado de uma obra conceitual não se instala dentro de si. Mas através do lugar que ocupa e pelo qual participa".
} 
plastic quality, technique, or importance attached to it) (our translation) ${ }^{4}$

We highlight three proposals for the treatment of information of works of art. The first one, presented by Bevilacqua (2010), was about the work of the museologist Peter van Mensch, who proposed that the museum objects had three different matrices as sources of information: physical properties, functions and meanings, and history of the object.

The second proposal was presented by Maimone and Tálamo (2008, p.13); the authors stated that works of art should be "analyzed in terms of their content and peculiar characteristics, as well as their descriptive aspects using a standardized methodology". Thus, content analysis would cover description, identification, and interpretation of works of art, including the selection of information sources and documentary representation, which would result in the production of documentary summaries and keyword selection.

The third proposal is the methodology adopted by Guimarães and Araújo (2006) for image indexing and retrieval based on the visual content. The authors proposed a selection of metadata that would involve the use of taxonomy and selection of visual characteristics, producing content-independent metadata (format, author's name, date, etc.), content-dependent metadata (color, texture, shape, spatial relationship, etc.), and content-descriptive metadata (emotions, meanings, politics, etc.).

When analyzing a contemporary work of art as a document, including its particular conceptual characteristics, it is necessary to go beyond the descriptive representation of information. According to Baptista et al. (2010, p.69),

Physical description involves the identification of the physical characteristics of the object thus making it different from all others including, for example, elements such as author, title, publisher ISBN, etc. The elements identified are selected terms that make up a vocabulary represented by codes (our translation) ${ }^{5}$
The above cited literature on the methods of representation of information is primarily focused on traditional artistic productions such as painting, especially considering information aspects related to the pictorial image, in which the visual code will define the content to be treated and represented. However, in contemporary art productions, conceptual and even aesthetic relationships require a representation of information that should go beyond the mere physical description of the artwork.

It can be said that there is a marked tendency to homogenize the treatment of information in artistic productions, i.e., the so called classical artwork is represented the same way as contemporary artwork, focusing only on the categorization of information related to size, technique, plastic material, year, and artist, i.e., on the descriptive representation of objects.

Thus, the techniques, artistic concepts, social contexts, and the very structural composition of artistic production have undergone changes and no longer have the two-dimensional or three-dimensional shape and can even affect only the sensitivity of the viewer. This considerably changes the perceptual relationship between artwork and viewer, but the traditional practice of representing information remains. This traditional model, cannot handle the substantial amount of information and degree of perceptivity inherent in contemporary art productions, contributing, to some extent, to the restriction of information in the information retrieval process.

Therefore, the set of elements that make up a contemporary art object is seen as a system of interconnected networks in the form of a rhizome (Deleuze \& Guattari, 1980), and thus, it is necessary to consider the possibility of changes such as natural degradation, scenery or environmental changes, and insect pests and fungi that can damage these materials. Another thing to consider their own sign resignification dynamics, which results from a devir, i.e., a series of processing or constant transformation of contemporary art production materiality.

\footnotetext{
4 "Apesar da falta de padrão metodológico para tais questões, é possivel propor alguns critérios para a definição dos parâmetros de classificação e destinação desse tipo específico de material (que figuram entre o objeto artístico e o documento de arquivo): a intenção do artista (manifesta mais na proveniência do objeto e em sua configuração formal) - suporte, técnica, acabamento e apresentação e o caráter de obra finalizada (definido mais pela configuração formal do objeto e de sua apresentação do que pela qualidade plástica, técnica ou importância a ele atribuída)".

5 "O processo da descrição física envolve uma operação de identificar as características físicas do objeto tornando-o único, e inclui, por exemplo, elementos como autor, título, editor, ISBN, etc. Os elementos identificados são termos selecionados que compõem umvocabulário que está representado em códigos".
} 
This series of processing characterizes these artistic productions within the material phenomena of culture with different pace and dynamics, representing what Ingold (2012) calls "things", which would include artifacts, objects, landscapes, and other elements of a certain reality. In short, when considering other elements that are related to artwork, allowing identifying or inferring the relationships (Gell, 1998) established between the intrinsic and extrinsic properties of the artwork, it is possible to expand the universe of representation by including other actors in the process.

It is worth highlighting that the need to explain the poetic intentions of the artist and to establish criteria of concepts and representations of art are not being questioned. Rather, there is a great need to reflect about the development of new methods for the treatment of information, including the intrinsic and extrinsic information of works of art. This would facilitate the retrieval of information, contributing to research on the field of visual arts and to the analysis of cultural, social, and artistic aspects that reflect society issues. Therefore, according to Freire (1999, p.32),

Not surprisingly, researchers find it difficult to investigate artistic productions adopting the procedures inherent in the museological logic; therefore, the general public has little knowledge of museums' art collection (our translation) . $^{6}$

Since the interpretation should be made based on individual's knowledge and sociocultural relationships, it might occur through the relationship between fields of knowledge such as Museology, Visual Arts, and Information Science. This would enable a more direct engagement of professionals of these areas in terms of the epistemological characteristics that would enable the development of mechanisms to facilitate information retrieval, without interfering in the fruition; i.e., in the relationship between viewer and artwork.

At the same time, with regard to the representation of information, information science should point out that the presence of influencing issues are inevitable, "i.e., the representations influence public perceptions, allowing people to see (or not) certain
things"(Freire, 1999, p.55). For this reason, there is a need to increase the elements involved in the representation of works of art in order to enable easier understanding of artworks within social groups.

The fruition of the interaction between the viewer and artwork or between the work and a scientist is a significant element in the process of interpretation, and it could be a classification attribute in which each individual would, according to his/her prior knowledge, contextualize the artwork based on its representation.

According to Rodrigues and Crippa (2009, p.9), "fruition is a process that is understood over time, not necessarily during a visit to an art exhibition". Although the classification of museum objects generally focuses on descriptions that define the materials that contain information and techniques, it is possible that the information scientists that work with representation of information can come up with new methods of representation of information that could be used in other thematic categories. Therefore, constant effort and communication between professionals are necessary. Therefore, it ca be said that,

For a comprehensive artistic and educational fruition, the clarification of this process is fundamental because it reveals choices and resignify, critically and dynamically, the role of artworks in the museum collection (Bevilacqua, 2010, p.84, our translation) ${ }^{7}$.

Therefore, the extrinsic information resulting from the individuals involved in the processes of production and authenticity of contemporary works of art should be taken into consideration. The communication between the artist (producer), the curator (work of art administrator and manager), the art critic, the art historian (a person who studies artists and artwork history), and the information professional or information scientist is an essential element of sources of external information about the artwork. It would improve the representation of information, promote fruition, and contribute to the artistic cultural heritage of the society.

The fruition involves the perspective of the "new", provoking senses and perceptions, inciting recognition

\footnotetext{
$\overline{6}$ "Não por acaso, os pesquisadores encontram dificuldades para aplicar os procedimentos inerentes à lógica museológica ao investigar e expor tal produção, o que resulta no pouco conhecimento desse acervo por parte de um público mais amplo".

7 "Para uma fruição artística e educativa completa, o esclarecimento desse processo é fundamental, pois revela escolhas e ressignifica crítica e dinamicamente os papéis da obra de arte dentro do acervo museológico".
} 
and sensations (Barthes, 2013). Therefore, when the viewer confronts the artwork, creating new meanings to the signs, there is fruition and the "new" stimulates a reaction, establishing new significations and correlations with the cultural context in which the viewer is inserted. Using fruition to combine elements of information attributes can, in this context, be a challenge as it involves the use of perceptions and sensations caused by contemporary artworks. At the same time, it would create a unique experience for the symbolic construction of the representation of the information process.

Accordingly, we identified in our own studies the limited availability of information about representation of information in contemporary artworks since the aspect of fruition as a classification element was not taken into consideration in these studies. During the representation of information of artists' books in the Paraiba Center for Centro de Arte Contemporânea (NAC), some difficulties were encountered in representing the information related to the artwork concept and its influences and contexts; factors of extreme importance in conceptual productions. These extrinsic elements could be obtained from documentation related to the communication between these social actors or the fruition of the interaction between them.

However, it is important to clarify that the study carried out by Catoira (2012), focused mainly on the NAC's art collection in order to recuperate and systematize it, enabling visibility and, mainly, promoting its preservation. As it was not possible to handle all the information needs of the objects to be treated (the research involved a wide range of documents), some difficulties and issues related to the representation of information of artists'books were identified.

\section{Organization and representation of NAC's artists' books: Models and informational attributes}

The Center for Contemporary Art was established in 1978 in João Pessoa, capital city of Paraíba. During its first seven years it had a significant and prominent cultural and artistic role focused on contemporary art contributing to insert the Northeast region of Brazil into the national art circuit, previously restricted to the Rio de Janeiro - São Paulo axis.
The research based on a Master's degree studies at the Universidade Federal da Paraiba, graduate Program in Information Science, addressed the treatment and representation of information of part of NAC's collection, including newspaper clippings, administrative reports, curatorial texts for exhibitions, lists and inventories of the collection, art workshop materials, exhibition materials photographs, xerox art, postal art, negatives, posters, and finally the artists'books produced between 1978 to 1985 , period of time chosen for that study (Catoira, 2012).

During the treatment and organization of the NAC's artists' books, through the representation of information of these objects, it was observed the need to rethink and discuss this topic. It was observed in the documentation (which somehow proposed the organization and recording of the NAC's collection of artists'books) that its classification system was similar to that adopted to classify and catalog traditional books, creating a homogenization of the representation of information and hindering the differentiation of the NAC's literary collection.

Due to the homogenization of the treatment of traditional and artists'books, methodological procedures that would not hinder the possibilities of carrying out their treatment, were used. An artisanal model that enabled the adaptation of general principles to specific research situations was chosen (Becker, 1997).

With regard to the relationship between the notions of a field, a "notional system" is considered, which establishes a specific framework for the organization of information (Cintra et al., 1994). Therefore, the classification system adopted was based on a notional system of fields of knowledge, which was used throughout this study. This classification system concerned the semantic aspects in order to enable a treatment that aimed to relate the objects in the NAC's collection to their context, leading to the connection between the representation of information of these materials and their contextual universe. Thus, this representation allowed respecting the forms of signification of the conceptual universe of contemporary art.

Codes and systems were created based on an open classification that evidenced the possibilities of new restructuring and signification since it was understood that the classification is included in the unlimited semiosis 
process; in other words, the classification of information based on a semiotic analysis has different interpretations in the different contexts in which it may occur. In this sence, in the unlimited Semiosis is the endless process by which signs give birth to other signs within the communication process forming a multidimensional network of meanings, in which each one of these signs will be interpreted according to the social context in which it is inserted, as well as to the cultural background of the interpreter (Eco, 2000; Santaella, 2008).

Different methods, such as documentary analysis, were used to develop the organizational model, which was linked to the interpretation of information using signs (specific attributes) to represent the documents in order to treat the information thoroughly, generating new information. It is worth mentioning that this information can go beyond the perception of the object materiality; therefore, the information scientist cannot handle the totality of information (intrinsic and extrinsic). When referring to especific atributes in the field of information science, the term "attributes" has the same function as metadata. Thus, "[...] sets of attributes, more specifically reference data that represent the information content of an resource, which can be an electronic resource or not [...]" (Alves, 2005, p.115).

It was also considered the subject-object relationship, in which when the interpreter transpose the object in its materiality to the written document format using controlled language, the process is complex, limited, and slow. This process can also be characterized as a fruition process, which makes it an important action, especially for the field of memory and cultural heritage, in which it is essential to establish a cultural significance, justifying the object's conservation and preservation (Ceravolo, 2010). However, in this case, the fruition, was limited to the interaction between the object and the researcher only, reducing the possibility of more information to be interpreted. One that the controlled language is considered as terms used in the NAC's collection of documents and the words that are used in the social-historical context of this art center and refer to other documents that cite or mention NAC's activities, exhibitions, and collection.

The organization and classification of the documents used in this study were based on traditional organizational models and inventories that are effective in the organization of contemporary art collections and are used by other art institutions, such as the Museu de Arte Contemporânea da Universidade de São Paulo (Contemporary Art Museum of the University of São Paulo) and the Fine Arts \& Architecture Library of the University of Utah. Their art collection and inventory are available on their website, which contributed to the development of the classification model and inventory in this research (Catoira \& Azevedo Netto, 2013).

Therefore, it was possible to identify traditional models that are used in the treatment of contemporary artwork, but, as previously mentioned, these models are focused on traditional art works and therefore have limited attributes for the representation of information, like the common model used to represent traditional literature books.

As for the artists' books of the Paraiba Center for Contemporary Art that were treated, the representation of information of these objects narrowed or limited the information materiality, promoting the understanding of the object structure only. Additionally, the lack of documentation, information, and communication with other actors involved in these artists'books, reduced the chances to formulate their concept as artwork and did not allow the addition of new representations.

We needed a language that could thoroughly and accurately describe and represent the NAC's artists'books; therefore, we chose a language that could serve as a proposition, character, articulation, and criticism focusing on the visibility of the object. The representation of information was based on semiotic analysis since the representation from a cognitive, social, and structural perspective is essential for information access, allowing the representation to have the role of a mediator between the source and the user (Azevedo Netto, 2008b).

Accordingly, a specific model/system was developed for the NAC's artists'books including catalogs and inventories that were prepared based on the documents of the NAC's collection, through representation and classification. The interpretation and transposition of documents to the organizational models and their specific signs were performed using a controlled language of the art collection. 
The representation of information of these documents using a controlled language enabled the signs (which represented the documents of this collection) to facilitate information access, allowing all information to be perceived and used as knowledge, establishing new signification and providing an effective and dynamic information retrieval.

The particularities of each information support were analyzed so that the catalogs (with organizational models) could be used in the description of each material in the collection, which had a significant amount of specific information of each one of the objects. The inventories were used to (re)present the information obtained concisely, providing an overview of each type of material as a whole.

In the field of information science, the process of representing the object as language through the mediation and interpretation of information source (representation of information) leads to the organization and treatment of the information and can be used for knowledge construction and resignification. The informational sources can be material and/or immaterial and can have an informative potential (Azevedo Netto, 2002; Ceravolo, 2010).

As the present study sought to establish a relationship between information science and visual arts, it is important to understand that the every field of knowledge has its own set of ideas or a conceptual universe. Therefore,

The notional universe (conceptual universe) of the specialized areas of human experience have to be properly identified from a given point of view in order to be organized in a systematic way, i.e., interrelated. Only the notional organization of an area allows the use of effective tools for the treatment and retrieval of information (Cintra et al., 1994, p.49, our translation) ${ }^{8}$.
From a particular point of view of the NAC's art collection, the relationships and properties that are common to a certain class of objects were established, making it possible to observe the different forms of its organization. Considering the notions of an area of knowledge, it was important to understand its notional system that would be used based on a specific framework for the organization of information (Cintra et al., 1994).

Another information attribute used in the representation and retrieval of information was the addition of pictorial elements, such as visual information. It is evident that,

Despite the communicative effectiveness of visual images (present in the gestures, colors, clothes, etc.), information processing systems focus on verbal communication, whose language is used for logical-semantic control and standardizations modulating its decodification. However, it is known that both the visual discourse (more expressive, emotional, and concrete) and the verbal discourse (logical, conceptual, and abstract) are complementary forms of communication and are perfectly compatible with the information systems (Maimone \& Tálamo, 2008, p.50, our translation) ${ }^{9}$.

In addition to contributing to the representation of information, the pictorial representation also served as a link between the past and the present, evoking memories, creating a sense of belonging, and developing a close relationship between the object and the viewer. This pictorial sign was added to all documents of the collection that were organized, and this attribute was denominated as Visual Reference. It was used as an info-pictorial representation of the objects (scanned or photographed) seeking enhancement and efficiency of information retrieval, as well as to promote a future availability of these documents on the Internet.

The inclusion of pictorial elements in the organizational models was not intended to a

\footnotetext{
8 "As áreas especializadas da experiência humana devem ter seu universo nocional devidamente identificado a partir de um dado ponto de vista, para que seja possivel organizá-lo de forma sistemática, ou seja, inter-relacionada. Só a organização nocional de uma área permite a utilização de instrumentos eficazes para o tratamento erecuperação da informação".

9 "Apesar da eficácia comunicativa das imagens visuais (presentes nos gestos, nas cores, nas vestimentas, etc.), os sistemas de processamento de informação priorizaram a comunicação verbal, cuja linguagem se presta a controles lógico-semânticos e padronizaçōes, modulando sua decodificação. Reconhece-se, porém, que tanto o discurso visual - mais expressivo, emocional e concreto-, quanto o verbal - lógico, conceitual e abstrato - são formas de comunicação complementares eperfeitamente compatíveis com os sistemas de informação".
} 
Documentary Analysis of Images, but rather to analyze the information within its "three-dimensional matrix", i.e., its characteristics as an object, and to provide new insight into the identification methods by performing a visual representation and a memory representation of the informational object (Loureiro, 2000). Not wanted in this regard, carry out a documentary analysis in its methodological sense, since one of the main theories of Documentary Analysis of Image is based on the study by Panofsky (1979), which focused on the understanding of the image based on description, analysis, and interpretation. This type of analysis seeks to follow the Good Documentation Practices to retrieve image content attributes through representation. Other models of Documentary Analysis of Image addressing images'visual content have been mentioned in Information Science, such as that proposed in different perspectives, by Smit (1996) and Guimarães and Araújo (2006).

The hierarchical classification of the documents, established through the organization models and inventories, provided information of each object; and chronology, one of the classification attributes, contributed to the systematization and building of a "panorama" that includes more than information, enabling to organize and promote the resignification of the memories of this art collection.

The representation of information of the artists' books corresponded to the proposals of the research methodology in terms of the documentary analysis used and the informative structure of the objects. However, as previously mentioned, it was not possible to describe more relational and procedural information of the artists' books, resulting in a representation of the information very close to that of the traditional models. Therefore, new ideas have arisen, mainly regarding the representation of information of conceptual art productions considering fruition as a way to enhance and overcome the limitations of the representation of information in the field of Information Science.

\section{Conclusion}

In contemporary art, as observed, the classification and organization of art collections are a matter of concern since when artistic productions are processed in these types of representation systems, they may not adequately represent the meaning and the artist's intent or the context for which they were created.

If the methods used to represent information of contemporary artworks are not questioned, especially regarding conceptual productions such as artists'books, the representation of information will be restricted to a single and enduring model, which is able to reveal or provide only reference and descriptive data based on physical characteristics and specific information (dimensions, techniques, title, author, year, etc.).

Thus, there is the need to perform the representation of information considering fruition as a new informational attribute, which includes spatialtemporal and socio-cultural relationships and does not interfere or limits the freedom in the relationship between artwork and viewer (information scientist and professional). This could offer new possibilities to the representation of information of contemporary artworks. Considering fruiton, the representation could be used in other contexts and materials that contain information, aiming to contribute to research and retrieval of information, especially in terms of issues related to the preservation of social, institutional, and individual memories as it involves elements that affect the sensory and emotion perceptions.

Fruition as an important attribute in the representation of information, based on the principles of genetic criticism (which proposes the discussion of the creative process), would consider the artwork as unfinished, stimulating the search for other informational records and support, taking into account its perceptual relationships, also serving as an alternative source of information. Accordingly, the use of conceptual models that adopt new forms of representation and are not focused on defining classification attributes for the specificities of contemporary art productions can be considered as a viable alternative.

Thus, the use of these systems leads to the reflection on users' search needs, i.e., the aim is not only to describe basic information (physical and characteristic description), but also to present its concept (informational content), whether intellectual or artistic, highlighting its artistic expression through the communication between the artist and other important 
actors in the institutional process and in the production of the artwork.

Therefore, Information Science and studies in this field should focus on the representation of information, considering these aspects related to the fruition of the interaction between those involved in this system as sources of information that can be treated and organized enabling research and access; in other words, the interpretation of the information scientist can contribute to this goal.

Considering the fruition of the actors involved with the works of art by selecting the terms they use, would enable not only to include information about the artwork, but also to preserve its memory and the artist's memory. Based on these issues and discussions about the representation of information of contemporary productions, compared to conventional models established in a traditional way, the present study sought to find alternatives that enable strengthening the informational relationship between artist, artwork, and viewers in order to broaden the viewer/users' understanding and increase the representation of the memory of the artwork as a document, facilitating information retrieval and contributing to the preservation of memories, culture, and identities.

\section{References}

Alves, R.C.V. Web semântica: uma análise focada no uso de metadados. 2005. Dissertação (Mestrado em Ciência da Informação) - Faculdade de Filosofia e Ciências, Universidade Estadual Paulista, Marília, 2005.

Archer, M. Arte contemporânea: uma história concisa. São Paulo: Martins Fontes, 2001.

Azevedo Netto, C.X. Signo, sinal e informação: as relações de construção e transferência de significados. Informação e Sociedade: Estudos, v.12, n.2, p.1-13, 2002.

Azevedo Netto, C.X. Informação e patrimônio arqueológico: formações de memórias e construções de identidades. In: Encontro Nacional de Pesquisa em Ciência da Informação, 9., 2008, São Paulo. Anais... São Paulo: Universidade de São Paulo, p.1-12, 2008a. Disponível em: <http://enancib.ibict.br/ index.php/enancib/ixenancib/paper/viewFile/3001/2127>. Acesso em: 10 fev. 2016

Azevedo Netto, C.X. Abordagem do conceito como estrutura semiótica. Transinformação, v.20, p.47-58, 2008b. Disponível em: <http://www.scielo.br/pdf/tinf/v20n1/04.pdf>. Acesso em: 10 fev. 2016

Baptista, D.M.; Araújo Jr., R.H.; Carlan, E. Atributos dos Requisitos Funcionais para Registros Bibliográficos (FRBR). In: Robredo,
It can be said that today there is a tendency to homogenize the treatment of information of artistic productions, focusing on the descriptive representation of objects. However, it is possible to use new forms to represent information and the fruition of the interaction of the information scientist and information professional with the artwork and with other actors involved, aiming at the enhancement of conceptual art.

Fruition can be considered as a classification category in processes of representation of information, as it involves the communication and relationship between artwork and viewer causing multiple and endless interferences of significations. It could be a promising alternative to the inclusion of new information. Using fruition means to consider the aspects related to perception, straightening the relationship between the information scientist and the sensitive, obscure, and provocative nature of contemporary artworks.

\section{Collaboration}

All authors contributed to the conception, conceptual and theoretical foundations of the study, analysis and final editing.

J.; Bräscher, M. (Org.). Passeios no bosque da informação: estudos sobre representação e organização da informação e do conhecimento. Brasília: IBICT, 2010. p.61-80. Disponível em: $<$ http://www.ibict.br/publicacoes/eroic.pdf>. Acesso em: 30 jan. 2016.

Barthes, R. O prazer do texto. 6.ed. São Paulo. Perspectiva, 2013.

Becker, H.S. Métodos de pesquisa em Ciências Sociais. 3.ed. São Paulo: Hucitec, 1997.

Bevilacqua, G.M.F. Bancos de dados e informatização de arquivos: pressupostos teóricos e aplicações técnicas. 2010. Dissertação (Mestrado em História Social) - Faculdade de Filosofia, Letras e Ciências Humanas, Universidade de São Paulo, São Paulo, 2010

Brasil. Ministério do Trabalho e Emprego. Classificação Brasileira de Ocupações. Brasília: MET, 2002.

Catoira, T. Informação e arte: memórias e representação do acervo do Núcleo de Arte Contemporânea da Paraíba. 2012. Dissertação (Mestrado em Ciência da Informação) - Programa de Pós-Graduação em Ciência da Informação, Universidade Federal da Paraíba, João Pessoa, 2012. 
Catoira, T.; Azevedo Netto, C.X. Ciência da Informação e Museus de Arte na web: memória e representação das informações de obras de arte nas nuvens. Conferência sobre Tecnologia, Cultura e Memória: Estratégias para a Preservação e Acesso à Informação - CTCM, 2013, Recife. Anais eletrônicos... Recife: UFPE, 2013. Disponível em: <http://www.liber.ufpe.br/ ctcm2013/anais/files/9c.CIMAWEB.pdf>. Acesso em: 15 jun. 2014.

Cauquelin, A. Arte contemporânea: uma introdução. São Paulo: Martins, 2005. (Coleção Todas as Artes).

Ceravolo, S.M. Memória, arquivos, bibliotecas e museus: algumas reflexões. In: Murguia, E.I. Memória: um lugar de diálogo para arquivos, bibliotecas e museus. São Carlos: Compacta Gráfica e Editora, 2010.

Cintra, A.M.M.; Kobashi, N.Y.; Lara, M.L.G. Para entender as linguagens documentárias. São Paulo: Polis; APB, 1994.

Coelho, P.A. Metáfora dos "objetos deflagados", anos 70: as fronteiras da memória e da identidade na Arte Conceitual brasileira. 2006. Dissertação (Mestrado em Memória Social) Centro de Ciências Humanas e Sociais, Universidade Federal do Estado do Rio de Janeiro, Rio de Janeiro, 2006.

Deleuze, G.; Guattari, F. Capitalism et Schizophrénie: Paris: Editions de Minuit, 1980.

Eco, H. Os limites da interpretação. São Paulo: Perspectiva, 2000.

Freire, C. Poéticas do processo: arte conceitual no museu. São Paulo: lluminuras, 1999.

Freire, C. Artista/curadores/arquivistas: políticas de arquivo e a construção das memórias da arte contemporânea. In: Freire, C.; Longoni, A. (Org.). Conceitualismos do Sul. São Paulo: Annablum, 2009. p.13-24.

Gell, A. Art and agency: an anthropological theory. Oxford: Clarendon, 1998.

Guimarães, S.J.F.; Araújo, A.A. Introdução à recuperação de informação baseada no conteúdo visual. In: Nazário, L.; Franca, P. (Ed.). Concepções contemporâneas da arte. Belo Horizonte: Editora da UFMG, 2006. p.277-291.

Ingold, T. Trazendo as coisas de volta à vida: emaranhados criativos num mundo de materiais. Horizontes Antropológicos, v.18, n.37, p.25-44, 2012

Knappett, C. Materiality. In: Hodder, I. (Ed.). Archaeological theory today. $2^{\text {nd }}$. Cambridge: Polity Press, 2012. p.188-207.

Latour, B. Jamais fomos modernos: ensaio de Antropologia Simétrica. Rio de Janeiro: Editora 34, 1994.
Loureiro, J.M.M. Socialização da informação: nadando contra a corrente. Informação \& Sociedade, v.2, n.2, p.81-93, 2002. Disponível em: <http://www.ies.ufpb.br/ojs/index.php/ies/ article/view/142/136>. Acesso em: 15 fev. 2016.

Loureiro, M.L.N. A obra de arte musealizada: de objetos de contemplação à fonte de informação. In: Lima, D.F.C. et al. (Org.). Interdiscursos da Ciência da Informação: arte, museu e imagem. Rio de Janeiro: Brasília: IBICIT, 2000.

Maimone, G.D.; Tálamo, M.F.G.M. Tratamento informacional de imagens artístico-pictóricas no contexto da Ciência da Informação. Datagramazero, v.9, n.2, 2008. Disponível em: <http://periodicos.ufpb.br/ojs/index.php/pbcib/article/ view/5272>. Acesso em: 15 fev. 2016.

Martins, R. P. Informação e conhecimento: uma abordagem dos sistemas de recuperação de informações a partir das interações sociais. Perspectivas da Ciência da Informação, v.13, n.2, p.77-87, 2008. Disponível em: <http://www.scielo.br/pdf/ pci/v13n2/a07v13n2.pdf>. Acesso em: 15 fev. 2016.

Ortiz Ramos, J.M.; Bueno, M.L. Cultura audiovisual e arte contemporânea. São Paulo em Perspectiva, v.15, n.3, p.10-17, 2001. <http://dx.doi.org/10.1590/S0102-8839200100030 0003>.

Pacheco, L,S. Informação enquanto artefato. Informare: Cadernos do Programa de Pós-Graduação em Ciência da Informação, v.1, n.1, p.20-24, 1995.

Panofsky, E. Significado nas artes visuais. 2.ed. São Paulo: Perspectiva, 1979.

Pinheiro, L.V.R. Arte, objeto artístico, documento e informação em museus. In: Conferência Anual do ICOFOM e UNIRIO, 18. 1996, Rio de Janeiro. Simpósio Museólogo e Arte. Rio de Janeiro: Tacnet Cultural, [199-]. p.8-14.

Pinho, F.A. Fundamentos da organização e representação do conhecimento. Recife: Editora da UFPE, 2009.

Rodrigues, B.C.; Crippa, G. A Ciência da Informação e suas relações com a arte e com o museu de arte. Biblionline, v.5, n.1/2, p.1-14, 2009. Disponível em: <http://www.ies.ufpb.br/ ojs/index.php/biblio/article/view/3942/3107>. Acesso em: 16 fev. 2016.

Santaella, L. O que é semiótica. São Paulo: Brasiliense, 2008.

Silveira, P.A. A página violada: da ternura à injúria na construção do livro de artista. Porto Alegre: Ed. UFRGS, 2008.

Smit, J.W. A representação da Imagem. Informare: Cadernos do Programa de Pós-Graduação em Ciência da Informação, v.2, n.2, p.28-36, 1996. 